\title{
Organic Carbon Storage in Evergreen Oak Forest Ecosystems of the Middle and High Moroccan Atlas Areas
}

\author{
Mohamed Boulmane ${ }^{1 *}$, María del Carmen Santa-Regina ${ }^{2}$, Mohamed Halim ${ }^{3}$, \\ Abderrahim Khia ${ }^{4}$, Hayat Oubrahim ${ }^{3}$, Hassan Abbassi ${ }^{3}$, Ignacio Santa-Regina ${ }^{5}$ \\ ${ }^{1}$ Forest Research Center, B.P. 763, Av. Omar Ibn Khattab, Agdal, Morocco \\ ${ }^{2}$ Faculty of Biology, Campus Miguel de Unamuno, C/Donantes de Sangre, s/n, Salamanca, Spain \\ ${ }^{3}$ Faculty of Sciences Mohamed V, Agdal, Morocco \\ ${ }^{4}$ Faculty of Sciences Ibn Tofail, Kénitra, Morocco \\ ${ }^{5}$ Institute of Natural Resources and Agrobiology of Salamanca, IRNASA-CSIC, Salamanca, Spain \\ Email: "Ignacio.santaregina@irnasa.csic.es
}

Received 12 February 2015; accepted 9 March 2015; published 13 March 2015

Copyright (C) 2015 by authors and Scientific Research Publishing Inc.

This work is licensed under the Creative Commons Attribution International License (CC BY). http://creativecommons.org/licenses/by/4.0/

c) (i) Open Access

\section{Abstract}

We report carbon stock in biomass, litter and soil estimated for six locations in natural Quercus ilex L. stands of the Middle and High Moroccan Atlas. Twenty trees at each location were selected according to their diameter classes and felled to measure the biomass of trunk, branches, twigs and leaves and determine allometric relationships. Soil was sampled in five depths $(0-15,15$ - 30, $30-50,50-70$ and $70-100 \mathrm{~cm}$ ) and litterfall production measured in all tree stands. The total

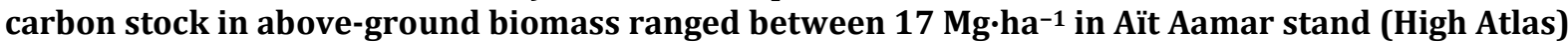
and $91 \mathrm{Mg} \cdot \mathrm{ha}^{-1}$ in Ksiba stand (Middle Atlas). Perennial organs (trunk, branches and twigs) stored over $95 \%$ of the tree carbon stock. Soil organic carbon concentrations ranged from $0.01 \%$ (in 70 $100 \mathrm{~cm}$ in all stands) to $8.1 \%$ (in $0-15 \mathrm{~cm}$ in the Ajdir stand in Middle Atlas). The total organic carbon stock in the soil ranged between $141.4 \mathrm{t} \cdot \mathrm{ha}^{-1}$ in Ajdir and $24.6 \mathrm{t} \cdot \mathrm{ha}^{-1}$ in Asloul. The litter

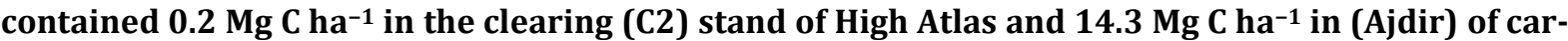
bon. The best fitted model for predicting carbon stock in tree biomass was obtained by applying the allometric equation $Y=a X^{b}$ for each biomass fraction and stand, where $Y$ is the aboveground biomass (dry weight) and $X$ is the DBH (Mean diameter at breast height, $1.30 \mathrm{~m}$ ). These previous data obtained in the present study confirm the important function of these natural forests as longterm C sinks, in forest biomass, litter and soil. The potential long term $\mathrm{C}$ storage of these systems is moderately high, especially in less-intensively managed forests that include large trees. The established relationship between DBH and carbon stock in different tree organs can be used for for-

\footnotetext{
*Corresponding author.
}

How to cite this paper: Boulmane, M., del Carmen Santa-Regina, M., Halim, M., Khia, A., Oubrahim, H., Abbassi, H., \& Santa-Regina, I. (2015). Organic Carbon Storage in Evergreen Oak Forest Ecosystems of the Middle and High Moroccan Atlas Areas. Open Journal of Forestry, 5, 260-273. http://dx.doi.org/10.4236/ojf.2015.53023 
est carbon accounting, and also synthesize available information on oak forest as a sink for atmospheric $\mathrm{CO}_{2}$, and identify the management options that may enhance the capacity for $\mathrm{C}$ capture/ storage in forest soils.

\section{Keywords}

\section{Allometric Methods, Bulk Density, Soil Organic Carbon, Vegetation}

\section{Introduction}

Carbon sequestration in forests helps to mitigate the accumulation of greenhouse gases in the atmosphere (Adams et al., 1999). Forests currently store a substantial stock of carbon, amounting to 826 billion metric tons in trees and soil (Brown, 1998). This stock can be further enhanced by implementing appropriate forest management strategies, such as regulating timber harvest intensity or rotational length (Murray 2000) and by increasing the land area under forests (Adams et al. 1999).

The amount of soil organic carbon in a forest is the result of an equilibrium among the primary net production of vegetation and the organic matter decomposition (Liski and Westman 1997a, b). Sometimes, the forest soils may become a significant source of $\mathrm{CO}_{2}$, followed by a climatic global warming, since this last could carry out a mineralization of organic matter, higher than the primary net production of vegetation (Liski 1999; Bernoux et al. 2005). Minor changes of organic carbon reservoir in the soil may significantly affect the $\mathrm{CO}_{2}$ concentration in the atmosphere, since the soil contains twice more carbon than the atmosphere (Schlesinger 1997; Post and Kwom 2000; Torn et al., 1997; Watson et al. 1990).

Greater differences were established on comparing the total amount of carbon in the aboveground biomass of different oak forests in Morocco. Ezzahiri et al. (1995) showed for Quercus ilex of Middle Atlas that the amount

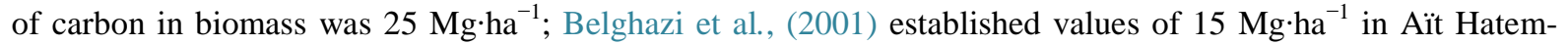
Oulmes. In the present study we have obtained higher values of carbon storage in forest stands of Middle Atlas (Dayat Hachlaf, Ajdir and Ksiba) and the stand of d'Ifghane in the High Atlas, and these amounts were similar to those obtained by Boulmane et al. (2010) in forest stands of Tafachna (53.7 Mg.ha ${ }^{-1}$ ) and Reggada (48.3

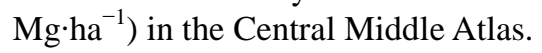

The production of litter in forests is mainly driven by biological processes and climatic factors (Santa-Regina \& Tarazona, 2001) although site topography, soil characteristics, species, forest age and density are also important factors. The rate at which nutrients are released depends on several factors: the chemical composition of the litter, the structural nature of the nutrient in the litter matrix, the microbial demand for the nutrient, and the availability of the exogenous nutrient sources. Litter release factors include litter quality (Gallardo et al., 1995), macro and micro-climatic variables and microbial and faunal biotic activity.

The forest of Quercus ilex L. is present throughout the Mediterranean area. It is particularly abundant in the western part. It is distributed in a continuous way from Tunisia through Turkey, to Spain (Boudy 1950; Schoenenberger 1975; Boulmane et al. 2013). These forests are the most productive in humid and sub-humid bioclimates. In semi-arid bioclimate, the stands are sparse and not very strong and appear often in the form of degraded bush. The Quercus ilex plays very important economical, environmental and social roles.

The estimation of net emissions of GES (Gaz à Effet de Serre) in Morocco in the 2010 are in the order of 75.4 Mt E- $\mathrm{CO}_{2}\left(2.27 \mathrm{t} \mathrm{E}-\mathrm{CO}_{2}\right.$ inhabitant $\left.{ }^{-1}\right)$. This shows that the Moroccan oak forests store aproximately 1/8 of GES issued by all Moroccan country. The analysis of net emissions per inhabitant confirms the very low contribution of Moroccan to emissions of GES (2.97 t E- $\mathrm{CO}_{2}$ in the 2020), despite there is an increase of $60 \%$ respect to the 1994 (1.84 t E-CO $)_{2}$ (M.A.T.U.H.E. 2010). This increase shows the rate of growth of a 1.4\% bigher than the rate of growth of population during this period (Boulmane et al. 2010).

The main aims of this study were to assess the amounts of carbon stored in the oak forest ecosystems in the Middle and High Moroccan Atlas areas (vegetation, soil and litter). This information can be used to design future strategies to preserve and improve these forests, and also synthesize available information on oak forest as a sink for atmospheric $\mathrm{CO}_{2}$, and identify the management options that may enhance the capacity for $\mathrm{C}$ capture/ storage in forest soils. 


\section{Materials and Methods}

\subsection{Site Description}

The research was carried out in six locations in the Moroccan Middle and High Atlas Central mountains (Figure 1). Three sampling plots of Quercus ilex (with an area of $10,000 \mathrm{~m}^{2}$ size plot) are located in the Moroccan Middle Atlas Central mountains in the forests of Dayat Hachlaf and Ajdir (province of Khenifra): its coordinates are $35^{\circ} 12.01^{\prime} 35 \mathrm{~N} \mathrm{~N}$ and $3^{\circ} 55.01^{\prime} 06^{\prime \prime} \mathrm{W}$ (at altitude of 1820 and 1730 m.a.s.l. (metres above sea level), respectively), Ksiba located in Beni Mellal province (at altitude of 1450 m.a.s.l.). The other three experimental plots are located in the Moroccan High Atlas Central mountains in the forests of Ait Aamar and Ifghane (province of Marrakech): $35^{\circ} 22.20^{\prime} 40^{\prime \prime} \mathrm{N}$ and $2^{\circ} 59.13^{\prime} 03^{\prime \prime} \mathrm{W}$ (at altitude of 1470 m.a.s.l.) and Asloul, province of Azilal (at altitude of 1460 m.a.s.l.) (Figure 1). All forest stands were characterized by natural regeneration and high growing stock, and the oak stands had not been previously subjected to any management regime. This forest ecosystem is the most representative of Morocco (representing over 29\% of the Moroccan forests (Boulmane et al. 2013). Its wood is used as fuel wood. Two clearings were also selected in both Moroccan Middle and High Atlas Central mountains to compare with these natural forest stands. Its coordinates are $35^{\circ} 12.011^{\prime} 35^{\prime \prime} \mathrm{N}$ and $3^{\circ} 55.01^{\prime} 06^{\prime \prime} \mathrm{W}$ and $35^{\circ} 22.20^{\prime} 40 " \mathrm{~N}$ and $2^{\circ} 59.13^{\prime} 03^{\prime \prime} \mathrm{W}$ for $\mathrm{C} 1$ and $\mathrm{C} 2$ respectively.

The main characteristics of the all plots are indicated in Table 1.

The general slope is close to $10 \%$, except in Ifghane plot where its slope is close to $5 \%$. The study area is dominated by chalky or dolomite substrates with generally basic soil $\mathrm{pH}$ and some limestone intercalations. The bulk density and carbonate data are also indicated in Table 2.

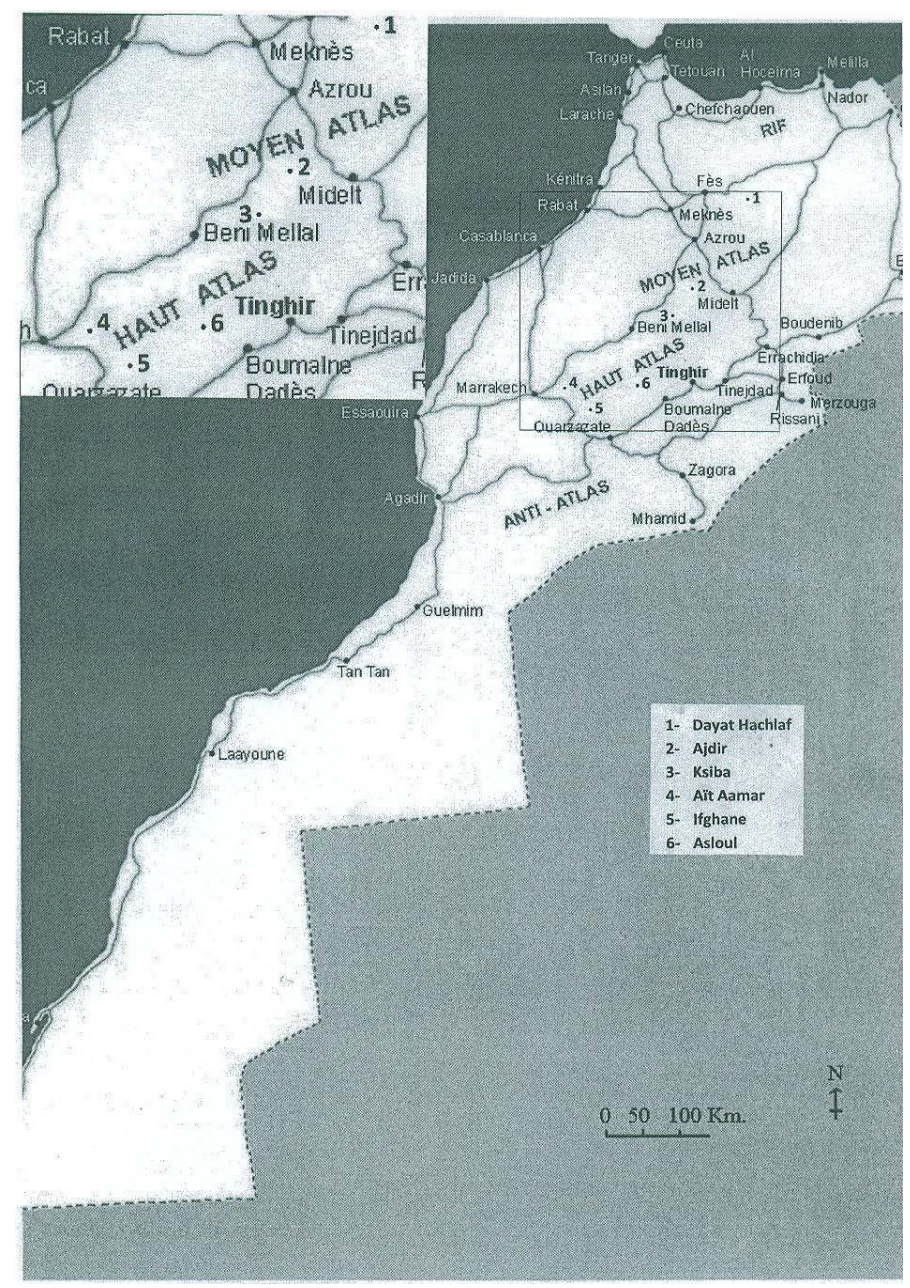

Figure 1. Localization of the six sampling forest stands. 
Table 1. Basic characteristics of the six study sites in evergreen oak forests in Middle and High Moroccan Atlas areas.

\begin{tabular}{|c|c|c|c|c|c|c|}
\hline \multirow{2}{*}{ Caption } & \multicolumn{3}{|c|}{ Middle Atlas } & \multicolumn{3}{|c|}{ High Atlas } \\
\hline & D. Hachlaf & Ajdir & Ksiba & A. Aamar & Ifghane & Asloul \\
\hline S.D.Q.i $\left(\right.$ trees $\left.\cdot \mathrm{ha}^{-1}\right)$ & 2826 & 2016 & 1560 & 384 & 464 & 996 \\
\hline B.A.QI $\left(m^{2}\right)$ & $21.7 \pm 4$ & $31.2 \pm 5$ & $32.8 \pm 5$ & $5.7 \pm 1$ & $5.6 \pm 0.9$ & $5.6 \pm 0.8$ \\
\hline C1.30 average.Q.i. $(\mathrm{cm})$ & $28.6 \pm 5$ & $37.7 \pm 6$ & $48.3 \pm 7$ & $39.6 \pm 7$ & $36.9 \pm 5$ & $25.5 \pm 3$ \\
\hline D.P. Other $\left(\right.$ trees $\left.\cdot h a^{-1}\right)$ & $\begin{array}{l}208 \text { (176: Ced., } \\
\text { 16: Ox. et 16: Le.) }\end{array}$ & $\begin{array}{c}108 \text { (68: Ced., } \\
\text { 16: Ox. et 24: Q.z.) }\end{array}$ & - & $\begin{array}{l}192(84 \text { Ox. } \\
\text { et } 108 \text { Th.) }\end{array}$ & $\begin{array}{l}84(72 \mathrm{Th} \\
\text { et } 12 \mathrm{Ox})\end{array}$ & 52 Ox. \\
\hline B.A.Other $\left(\mathrm{m}^{2}\right)$ & $\begin{array}{c}22.8 \text { (22: Ced., } \\
\text { 0.4: Ox. et 0.4: Le.) }\end{array}$ & $\begin{array}{l}45.23 \text { (41.2: Ced., } \\
\text { 0.03: Ox., 4: Q.z.) }\end{array}$ & - & $\begin{array}{c}1.82(0.7 \text { Ox. } \\
\text { et } 1.12 \text { Th. })\end{array}$ & $\begin{array}{c}0.33(0.32 \mathrm{Th} \text {. } \\
\text { et } 0.01 \text { Ox.) }\end{array}$ & $0.2 \mathrm{Ox}$. \\
\hline S.D.total $\left(\right.$ trees $\left.\cdot h^{-1}\right)$ & 3104 & 2124 & 1560 & 576 & 548 & 1048 \\
\hline B.A.total $\left(m^{2}\right)$ & $44.5 \pm 5$ & $76.4 \pm 12$ & $32.8 \pm 6$ & $7.4 \pm 1$ & $5.9 \pm 0.9$ & $5.8 \pm 0.8$ \\
\hline Altitude (m) & 1820 & 1730 & 1450 & 1470 & 1680 & 1460 \\
\hline $\operatorname{LAI}\left(\mathrm{m}^{2} \cdot \mathrm{m}^{-2}\right)$ & 2.2 & 2.0 & 1.9 & 1.8 & 1.9 & 1.8 \\
\hline rainfall $\left(\mathrm{mm} \cdot \mathrm{yr}^{-1}\right)$ & $1090 \pm 125$ & $890 \pm 98$ & $780 \pm 67$ & $544 \pm 46$ & $658 \pm 68$ & $776 \pm 83$ \\
\hline Annual average $\mathrm{T}\left({ }^{\circ} \mathrm{C}\right)$ & $13.3 \pm 1.2$ & $13.6 \pm 1.3$ & $12.9 \pm 1.2$ & $12.1 \pm 1.0$ & $11.9 \pm 0.9$ & $11.8 \pm 0.7$ \\
\hline Age of stand (years) & 70 & 64 & - & _ & 73 & ـ \\
\hline
\end{tabular}

S.D.: Stand Density, Q.i.: Quercus ilex, Q.z: Quercus Zeen, C.: Circumference, Le: leaf, Ox.: Oxycedar, Th.: Thuya, Ced.: Cedar, B.A.: Basal area, S.D.Q.: Stand density of Quercus ilex, LAI: Leaf Area Index , D. Hachlaf: Dayat Hachlaf and A. Aamar: Aït Aamar.

\subsection{Soil and Biomass Sampling and Chemical Analyses}

Soil samples were sampled on September 2010, from five layers (0 - 15, 15 - 30, 30 - 50, 50 - 70 and 70 - 100 $\mathrm{cm}$ ) for each plot. Given the high burden stony soil, sampling was limited to five samples pools for each depth in each plot (four on top elevation and the middle of the plot). Percentage of soil organic carbon in the dept soil intervals of the eight forest stands are shown in Figure 2(a), Figure 2(b). All Soil samples were dried at $65^{\circ} \mathrm{C}$ for 48 hours to constant weight and were ground and sieved at $2 \mathrm{~mm}$, to determine the soil organic carbon in the fine fraction $(<2 \mathrm{~mm})$ of each horizon by oxidation in acidic medium (Walkley and Black 1934), and grounded in a ball or ring mill to obtain a homogeneous particle size before being analysed for C. Stone content was negligible. Any stones present and coarse fragments were removed by hand and the soil was ground to pass a 0.5 $\mathrm{mm}$ mesh. The carbon stock at a sampling point was the sum of the stocks at each sampling level, calculated as of carbon content (in $\mathrm{gC} / \mathrm{kg}$ ) multiplied by the soil bulk density (in $\mathrm{kg} / \mathrm{dm}^{3}$ ) and the layer thickness (in $\mathrm{cm}$ ).

The carbonates content of the fine fraction $(<2 \mathrm{~mm})$ was determined by calcimetry and the particle size analysis by Robinson pipette method. All these analyses show that all experimental plots very rich in silt content $(\% \geq$ $45)$ and carbonates $(\% \geq 15 \%)$ (Table 2$)$.

Twenty trees in each sampled stand were subjectively selected to represent the diameter classes of DBH at $1.30 \mathrm{~m}$ defined from the experimental inventory, and were felled for subsequent biomass measurements and construction of equations for predicting tree biomass and carbon content. Three branches per level (low, middle, upper canopy) were selected. For each branch, three pieces of about $2 \mathrm{~cm}$ were cut (low, middle and top of the branch). Twigs and leaves were also collected at the low, middle and top of each branch. All of each sample was homogenized, then about $50 \mathrm{~g}$ of each compartment were placed in plastic bags for subsequent chemical analysis.

\subsection{Carbon Stock in Above-Ground Biomass of the Associated Trees (Cedrus atlantica (Endl..) G. Manetti ex Carrière and Thuja sp.)}

The stock of organic carbon pools contained in the aboveground biomass of the undergrowth was determined by cutting 15 shrubs (Oxycedrus) in each selected stand. So, the stock of organic carbon was assessed by multiplying the number of shrubs by the stock of organic carbon of the median shrub. 
Table 2. Physical and chemical characteristics of soil depth intervals at the study sites in evergreen oak forests and clearings in Middle and High Moroccan Atlas areas.

\begin{tabular}{|c|c|c|c|c|c|c|c|c|c|}
\hline & & D.H & Ajdir & Ksiba & A. Aa. & Ifghane & Asloul & C1 & C2 \\
\hline & $\mathrm{pH}$ & $7.4 \pm 0.2$ & $7.5 \pm 0.2$ & $7.8 \pm 0.2$ & $8.2 \pm 0.3$ & $7.9 \pm 0.2$ & $8.0 \pm 0.3$ & $7.8 \pm 0.2$ & $7.3 \pm 0.2$ \\
\hline & bd & $1.05 \pm 0.1$ & $1.03 \pm 0.01$ & $1.12 \pm 0.02$ & $1.31 \pm 0.03$ & $1.18 \pm 0.02$ & $1.21 \pm 0.02$ & $1.39 \pm 0.03$ & $1.40 \pm 0.04$ \\
\hline $0-15$ & \% Car. & $13.7 \pm 1.2$ & $16.3 \pm 1.9$ & $21.4 \pm 2.3$ & $27.9 \pm 2.4$ & $26.5 \pm 2.4$ & $28.1 \pm 2.6$ & $17.9 \pm 2.3$ & $10.1 \pm 1.4$ \\
\hline
\end{tabular}

\begin{tabular}{rccccccccc}
\hline & pH & $7.5 \pm 0.2$ & $7.6 \pm 0.2$ & $7.9 \pm 0.2$ & $8.3 \pm 0.3$ & $8.1 \pm 0.3$ & $8.2 \pm 0.3$ & $7.8 \pm 0.2$ & $7.4 \pm 0.2$ \\
& bd & $1.15 \pm 0.02$ & $1.070 \pm 0.2$ & $1.21 \pm 0.03$ & $1.33 \pm 0.04$ & $1.27 \pm 0.03$ & $1.27 \pm 0.03$ & $1.42 \pm 0.05$ & $1.41 \pm 0.04$ \\
$15-30$ & \% Car. & $20.1 \pm 2.3$ & $18.3 \pm 1.7$ & $23.7 \pm 2.3$ & $28.6 \pm 2.6$ & $27.1 \pm 2.5$ & $26.1 \pm 2.4$ & $18.3 \pm 2.3$ & $12.7 \pm 1.1$
\end{tabular}

\begin{tabular}{rccccccccc}
\hline & pH & $7.6 \pm 0.2$ & $7.8 \pm 0.2$ & $8.1 \pm 0.3$ & $8.2 \pm 0.3$ & $8.1 \pm 0.3$ & $8.2 \pm 0.3$ & $7.8 \pm 0.2$ & $7.4 \pm 0.2$ \\
bd & $1.25 \pm 0.03$ & $1.15 \pm 0.03$ & $1.25 \pm 0.03$ & $1.35 \pm 0.03$ & $1.30 \pm 0.04$ & $1.32 \pm 0.04$ & $1.45 \pm 0.06$ & $1.42 \pm 0.05$ \\
$30-50$ & \% Car. & $15.4 \pm 1.9$ & $17.9 \pm 1.4$ & $20.5 \pm 2.3$ & $26.3 \pm 2.5$ & $24.3 \pm 2.4$ & $25.7 \pm 2.5$ & $14.1 \pm 1.4$ & $13.2 \pm 1.1$
\end{tabular}

\begin{tabular}{rccccccccc}
\hline & pH & $7.6 \pm 0.2$ & $8.0 \pm 0.2$ & $8.0 \pm 0.2$ & $8.4 \pm 0.3$ & $8.3 \pm 0.3$ & $8.1 \pm 0.2$ & $7.9 \pm 0.2$ & $7.5 \pm 0.2$ \\
& bd & $1.31 \pm 0.04$ & $1.27 \pm 0.04$ & $1.31 \pm 0.04$ & $1.37 \pm 0.04$ & $1.41 \pm 0.05$ & $1.37 \pm 0.04$ & $1.44 \pm 0.06$ & $1.45 \pm 0.06$ \\
$50-70$ & \% Car. & $16.1 \pm 1.9$ & $20.9 \pm 2.3$ & $22.3 \pm 2.3$ & $29.7 \pm 2.6$ & $28.2 \pm 2.4$ & $27.2 \pm 2.4$ & $19.1 \pm 2.3$ & $13.7 \pm 1.2$
\end{tabular}

\begin{tabular}{rccccccccc}
\hline & pH & $7.6 \pm 0.2$ & $7.9 \pm 0.2$ & $7.9 \pm 0.2$ & $8.6 \pm 0.3$ & $8.2 \pm 0.3$ & $8.3 \pm 0.3$ & $8.0 \pm 0.2$ & $7.6 \pm 0.2$ \\
$70-100$ & bd & $1.35 \pm 0.04$ & $1.39 \pm 0.04$ & $1.41 \pm 0.05$ & $1.41 \pm 0.05$ & $1.39 \pm 0.05$ & $1.41 \pm 0.05$ & $1.45 \pm 0.06$ & $1.44 \pm 0.06$ \\
& \% Car. & $17.1 \pm 1.9$ & $25.9 \pm 2.4$ & $28.3 \pm 2.5$ & $31.7 \pm 2.9$ & $28.2 \pm 2.6$ & $28.7 \pm 2.6$ & $20.7 \pm 1.9$ & $13.7 \pm 1.1$
\end{tabular}

C1.: Clearing 1; C2.: Clearing 2, D.H.: Dayat Hachlaf; A. Aa: Ait Aamar; \% Carb.: \% Carbonates (calcite + dolomite); bd: Bulk density.

To evaluate the carbon stock in the aboveground biomass of the associated trees (cedar, in the Middle Atlas and thuya in the High Atlas) we have applied the following equation:

$$
\begin{aligned}
& \text { SOC biomass }\left(\mathrm{Mg} \cdot \mathrm{ha}^{-1}\right) \\
& =\left[\left(\text { Total volume }\left(\mathrm{m}^{3} \cdot \mathrm{ha}^{-1}\right) * \text { Dry wood density }(\mathrm{Mg} \mathrm{DM} \mathrm{m}\right.\right. \\
&
\end{aligned}
$$

where SOC is the stock of organic carbon and DM is the dry matter.

The total tariffs of volume were determined by applying the following formulas:

$$
\begin{gathered}
V=0.01695\left(D_{1.30}\right)^{2.12} \quad \text { Ezzahiri et al., (data not published) for thuya of High Atlas } \\
\ln (V)=1.9689+2.0055 \ln \left(D_{1.30}\right)+0.6411 \ln \left(D_{1.30}\right) \\
\text { according to M'hirit \& Benziane (2006) for Middle Atlas cedar }
\end{gathered}
$$

where: $V$ : volume $\left(\mathrm{m}^{3}\right)$ and $D: \mathrm{DBH}$ at $1.30 \mathrm{~m}$. 


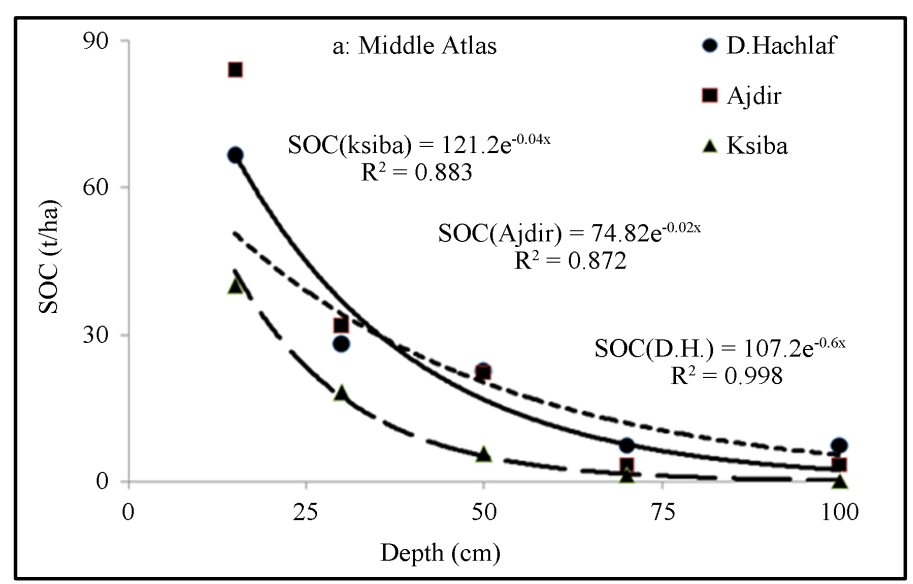

(a)

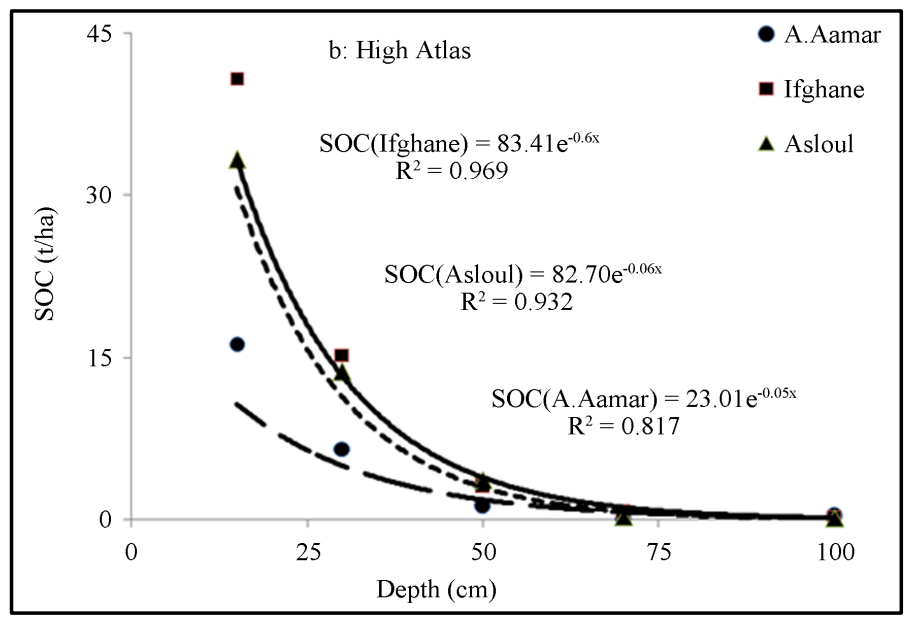

(b)

Figure 2. (a) (b) Changes of soil organic carbon $\left(\mathrm{t} \cdot \mathrm{h} \mathrm{a}^{-1}\right)$ relating to the depth soil intervals.

For litterfall measurement, twelve litter traps (spaced $10 \mathrm{~m}$ apart) were distributed in each plot. The first litter traps was placed randomly within each plot and the others were installed according to a network arrangement. Collection took place monthly from September 2005 to August 2008. In the laboratory, the samples were dried at $65^{\circ} \mathrm{C}$ for 72 hours, grounded, homogenized and expressed on a surface area basis (ha). Monthly and annual litterfall amounts were estimated from the monthly collected litterfall in the twelve litter traps on each plot.

\subsubsection{Measuring the Soil Bulk Density}

For each sampled layer the total weight of fine earth was determined on site after removing stones and sieving to $2 \mathrm{~mm}$ ). The moisture content of the fine fraction was calculated in the laboratory from a sample transported from the field in a sealed plastic bag. The total weight of the stones and $\geq 2 \mathrm{~m}$ fraction were also separated and on the ground. Their respective volume densities were determined through water displacement method using a pycnometer. We calculated the respective volume occupied by the fine earth fraction as:

(= total volume of sand - volume of stones - volume refusal to $2 \mathrm{~mm}$ ). The real density of the fine earth fraction (relative to the volume occupied by fine soil) in fine and bulk density based on the volume of the layer removed, can report the quantities of minerals hectare.

\subsubsection{Allometry}

The most common procedure for estimating amount of carbon in aboveground biomass in each forest stands is to use regression equations, based mostly on DBH (trunk diameter at $1.30 \mathrm{~m}$ ) as an explanatory variable (Rapp 
et al. 1999; Davi et al. 2005).

The updating models for estimating the amount of carbon distributed in different parts of the tree was done by the regression using the SAS (Statistical Analysis Software) (Instead of stating specific software commands give full detail on type of regressions used for the computation). The complete set of equations (for different biomass fractions) was obtained following Saint-André and Picard, 2005. The models tested were linear type $\mathrm{D}^{2} \mathrm{H}$ and non-linear in $\mathrm{D}^{2} \mathrm{H} . \mathrm{Y}=a X^{b}$, where $\mathrm{Y}$ is the aboveground biomass (dry weight) and $\mathrm{X}$ is the $\mathrm{DBH}$ at a height of 1.30 (Leonardi et al. 1996; Santa-Regina et al., 1997; Rapp et al., 1999; Santa-Regina 2000; Santa-Regina et al., 2001, and Santa-Regina and Tarazona, 2001).

The organic carbon storage in the different soil horizons was calculated as follows:

$$
\operatorname{SOC}(i)=0.1 \times E_{i} \times d a(i) \times C_{i}
$$

where:

$\operatorname{SOC}(i)$ : organic carbon storage in the soil horizon $(i)\left(\mathrm{t} \cdot \mathrm{ha}^{-1}\right)$,

$E_{i}:(i)$ horizon thickness (cm),

$d a(i)$ : Bulk density of fine-earth fraction $<2 \mathrm{~mm}$, in the horizon $(i)\left(\mathrm{g} \cdot \mathrm{cm}^{-3}\right)$,

$C_{i}$ : Organic carbon concentration of the fine-earth fraction in the horizon (i) $\left(\mathrm{g}^{\mathrm{kg}} \mathrm{kg}^{-1}\right)$.

The total organic carbon $(Q)$ storage in the soil profile is the sum of the sum of amounts in each horizon: $Q=\sum(q(i))$.

\section{Results}

\subsection{Soil Organic Carbon Content and Organic Matter Concentrations}

The soil organic carbon concentrations (\%) ranged from $0.01 \%$ to $8.1 \%$, with minimum values recorded in the $70-100 \mathrm{~cm}$ of all stands and maximum-in the $0-5 \mathrm{~cm}$ layer of Ajdir stand. The soils of the all stands were rich in organic matter $(\% \mathrm{OM} \geq 3$ in the depth of $0-30 \mathrm{~cm})$, except in those of Asloul and Ifghane $(1.5 \leq \% \mathrm{OM}$ $\leq 3$ ) and those of Aït Aamar, which were poor in the $15-30 \mathrm{~cm}$ depth, as well as the clearings of the Middle and High Atlas, which were very poor in organic matter $(\% \mathrm{OM} \leq 0.7)$.

The correlation study showed that the SOCs of forest soils were strongly dependent of the soil depth in different sampled forest stands (Figure 2(a), Figure 2(b)). They decreased following an exponential curve with a negative exponent in all stands selected, as well as the deviation among the organic carbon stocks of different depth intervals in all sampled stands decreased with the soil depth. The stock of total organic carbon content at a depths of $0-100 \mathrm{~cm}$ and $0-15 \mathrm{~cm}$ showed a relatively large reliance of the total basal area of the trees (Figure 3), whereas, the depths of (15 - $30 \mathrm{~cm}$ and $30-50 \mathrm{~cm}$ ) were less dependent than the other first depth. The stock of total organic carbon at a depth of $(50-70 \mathrm{~cm}$ and $70-100 \mathrm{~cm})$ was practically independent of the total basal area of the trees. No correlation was found between the stand density and the total organic carbon stored in the soil.

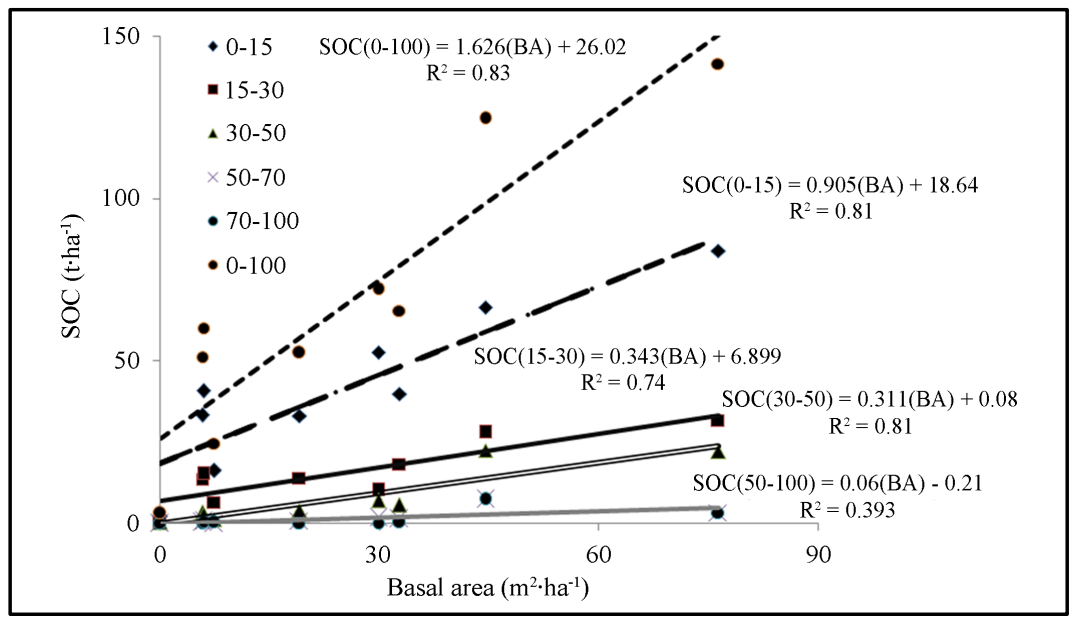

Figure 3. Changes of soil organic carbon $\left(\mathrm{t} \cdot \mathrm{ha}^{-1}\right)$ relating to the basal area $\left(\mathrm{m}^{2} \cdot \mathrm{ha}^{-1}\right)$. 


\subsection{Carbon Stocks in Tree Aboveground Biomass}

The structure of Quercus ilex trees of the six experimental evergreen oak forest stands studied of the Middle and High Moroccan Atlas areas, as well as the structure of the felled trees are reflected in the histograms of frequency (Figure 4). The distribution of the trees according to their diameter classes shows a regular structure between the different stands and displays a diameter class between $20-30 \mathrm{~cm}$ in all plots, apart from Ifghane and Ksiba stands, where their diameter classes were $40 \mathrm{~cm}$ and $50 \mathrm{~cm}$ respectively.

The weighted measures made from the 120 felled trees (20 per plot) have been used to establish the statistic relations linking the organic carbon amounts of the different organs of the trees (trunk, branches, twigs and leaves) and the DBH at $1.30 \mathrm{~m}$ of the oak forest stands in the Middle and High Atlas (Figures 5-7). Different correlations have been tested to establish the best correlated model of regression for each oak tree (Table 3).
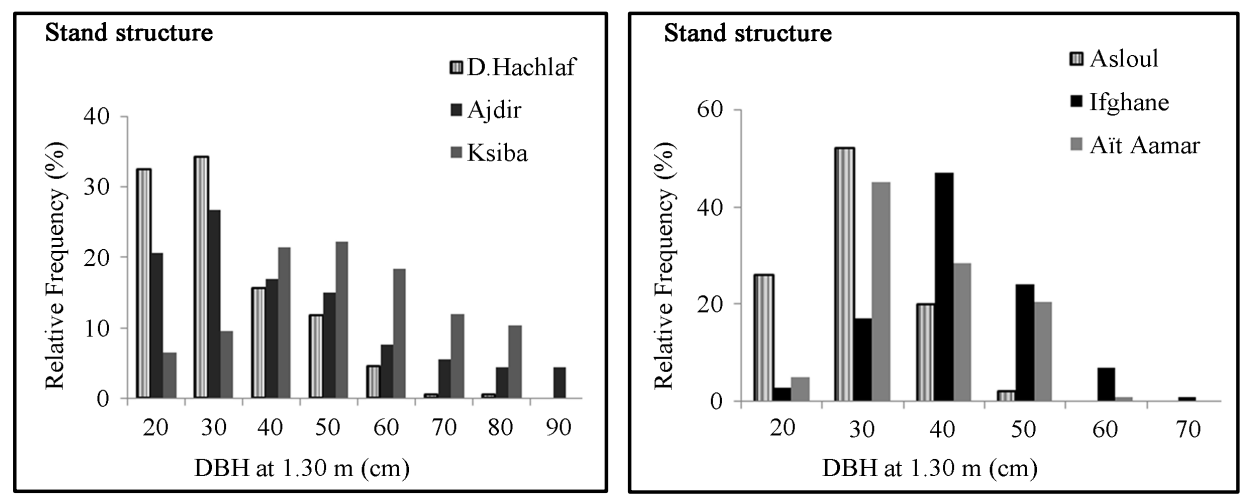

Figure 4. Structure of Quercus ilex trees in the all selected stands.
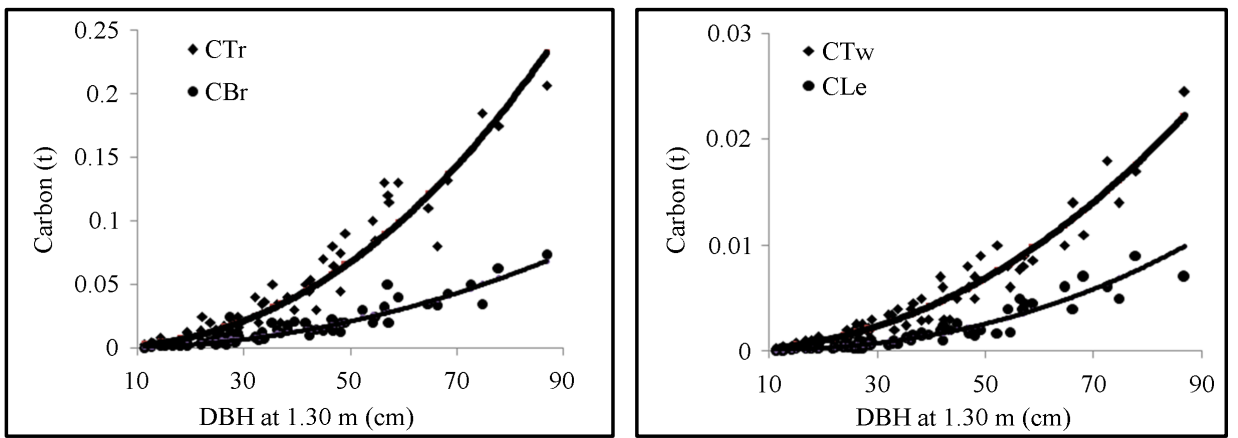

Figure 5. Adjustment of carbon amount in the different components relating DBH at $1.30 \mathrm{~m}$ of felled trees in the Middle Atlas stands. CTw: Stock of carbon in twigs; CLe: Stock of Carbon in Leaves; CTr: Stock of carbon in Trunk and CBr: Stock of carbon in Branches.
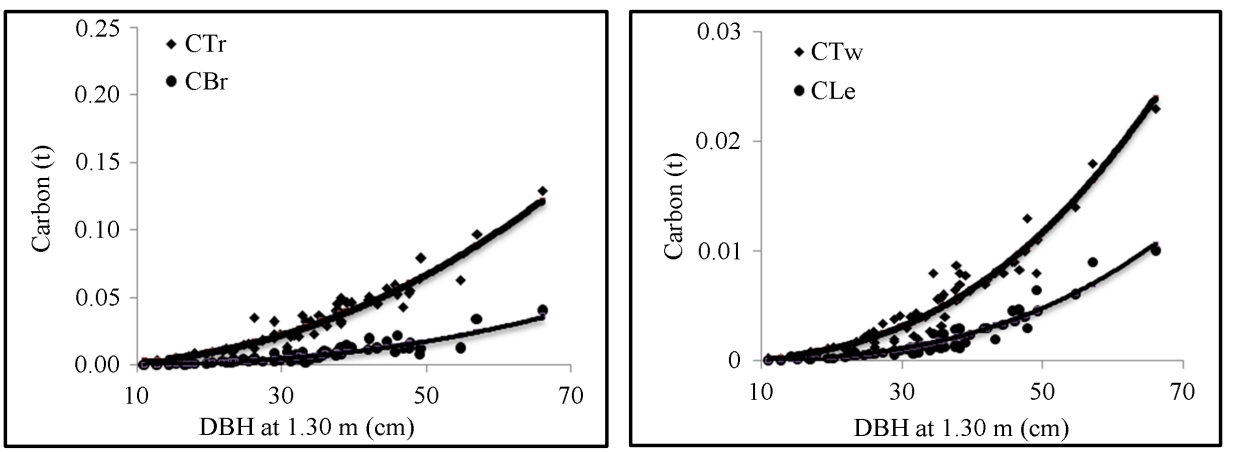

Figure 6. Adjustment of carbon amount in the different components relating DBH at $1.30 \mathrm{~m}$ of felled trees in the High Atlas stands. CTw: Stock of carbon in twigs; CLe: Stock of Carbon in Leaves; CTr: Stock of carbon in Trunk and CBr: Stock of carbon in Branches. 

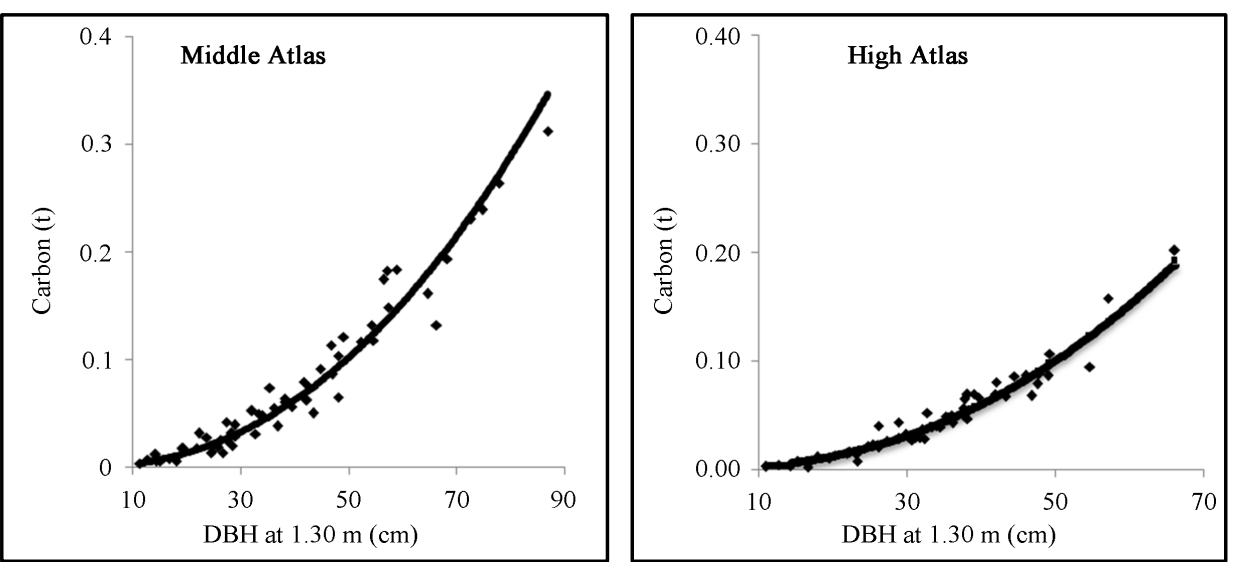

Figure 7. Adjustment of total carbon amount relating to DBH at $1.30 \mathrm{~m}$ of felled trees in the Middle and High Atlas stands.

Table 3. Adjusted models of amount of carbon in the different organs of the felled trees $(\mathrm{N}=120)$ in the Middle Atlas and High Atlas.

\begin{tabular}{ccccc}
\hline \multirow{2}{*}{ Tree organs } & \multicolumn{2}{c}{ Middle Atlas } & \multicolumn{2}{c}{ High Atlas } \\
\cline { 2 - 5 } & \multicolumn{1}{c}{ Adjusted models } & $\mathbf{R}^{2}$ & Adjusted models & $\mathbf{R}^{2}$ \\
\hline Trunk & $\mathrm{CTr}=32 \times 10^{-6} \times\left(\mathrm{C}_{1.3}\right)^{2.227}$ & 0.93 & $\mathrm{CTr}=30 \times 10^{-6} \times\left(\mathrm{C}_{1.3}\right)^{2.173}$ & 0.99 \\
Branches & $\mathrm{CBr}=6 \times 10^{-6} \times\left(\mathrm{C}_{1.3}\right)^{2.12}$ & 0.94 & $\mathrm{CBr}=10 \times 10^{-6} \times\left(\mathrm{C}_{1.3}\right)^{2.506}$ & 0.98 \\
Twigs & $\mathrm{CTw}=3 \times 10^{-6} \times\left(\mathrm{C}_{1.3}\right)^{2.13}$ & 0.94 & $\mathrm{CTw}=7 \times 10^{-6} \times\left(\mathrm{C}_{1.3}\right)^{2.586}$ & 0.97 \\
Leaves & $\mathrm{Cl}=1 \times 10^{-6} \times\left(\mathrm{C}_{1.3}\right)^{2.45}$ & 0.95 & $\mathrm{Cl}=4 \times 10^{-6} \times\left(\mathrm{C}_{1.3}\right)^{2.876}$ & 0.98 \\
Total & $\mathrm{Ct}=40 \times 10^{-6} \times\left(\mathrm{C}_{1.3}\right)^{2.21}$ & 0.94 & $\mathrm{Ct}=50 \times 10^{-6} \times\left(\mathrm{C}_{1.3}\right)^{2.28}$ & 0.99 \\
\hline
\end{tabular}

$\mathrm{C}_{1.30}$ : Diameter at $1.30 \mathrm{~m}$; Ctr: amount of carbon in trunk; Cbr: amount of carbon in branches; Ctw: amount of carbon in twigs; $\mathrm{Cl}$ : amount of carbon in leaves; Ct: total amount of carbon. The amounts of carbon are expressed in Kg of dry matter and $\mathrm{C}_{1.30}(\mathrm{~m})$.

Table 4 summarizes the overall set of achieved results from the regression equations of organic carbon stocks in the aboveground biomass for every oak select forests and their distribution by the different tree components. The stock of organic carbon in the tree aboveground biomass in the oak forests of Middle and High Moroccan

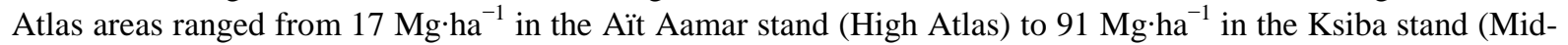
dle Atlas). In the perennial organs (trunk, branches and twigs was stored more than the $95 \%$ of organic carbon. Thus, in the oak forests of Middle Atlas there was more organic carbon stored in the aboveground biomass (55 -

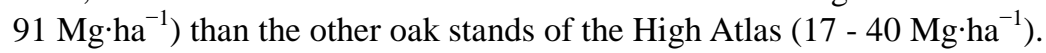

The results of organic carbon stocks in the tree aboveground biomass of the associated trees (cedar and thuya) are indicated in Table 5. These results may be deduce because of knowing the dry wood density of cedar ( 0.5 $\left.\mathrm{Mg} \cdot \mathrm{m}^{-3}\right)$, and the dry wood density of thuya $\left(0.56 \mathrm{Mg} \cdot \mathrm{m}^{-3}\right)$, the organic carbon content in the dry matter $(0.5 \%$ (GIEC, 2007)) and the DBH of all counted trees at $1.30 \mathrm{~m}$ (cedar and thuya).

\subsection{Amount of Carbon in the Undergrowth (Uuniperus oxycedrus)}

The amounts of carbon stored in the oxycedar of the different stands are summarized in Table 5. The percentage of carbon in the oxycedar stand respect to the oak stands was lower than $2 \%$, except in the two forest stands of the High Atlas (Aït Aamar and Asloul), where this percentage was about a 18\%.

\subsection{Amount of Carbon in Litter}

A clear difference was found respect to the amounts of carbon in litter related to the basal area of the stand (Figure 8). The terrestrial surface had a great effect on the storage of carbon in the soil litter, and varies among 
Table 4. Amount of carbon in biomass $\left(\mathrm{t} \cdot \mathrm{tree}^{-1}\right.$ ) of the different tree organs in the different oak selected stands of the Middle and High Atlas. Ctr: amount of carbon in trunk; Cbr: amount of carbon in branches; Ctw: amount of carbon in twigs; $\mathrm{Cl}$ : amount of carbon in leaves; $\mathrm{Ct}$ : total amount of carbon.

\begin{tabular}{ccccccc}
\hline & Stand & Ctr & Cbr & Ctw & Cl & Ct \\
\hline \multirow{3}{*}{$\begin{array}{c}\text { Middle } \\
\text { Atlas }\end{array}$} & D. Hachlaf & $\mathbf{3 4 . 7} \pm \mathbf{4 . 1}$ & $\mathbf{1 1 . 1} \pm \mathbf{2 . 2}$ & $\mathbf{7 . 2} \pm \mathbf{1 . 0}$ & $\mathbf{2 . 5} \pm \mathbf{0 . 2}$ & $\mathbf{5 5 . 5} \pm \mathbf{6 . 7}$ \\
& Ajdir & $\mathbf{5 6 . 0} \pm \mathbf{6 . 4}$ & $\mathbf{1 7 . 0} \pm \mathbf{2 . 5}$ & $\mathbf{1 1 . 0} \pm \mathbf{1 . 4}$ & $\mathbf{4 . 5} \pm \mathbf{0 . 3}$ & $\mathbf{8 8 . 5} \pm \mathbf{9 . 8}$ \\
& Ksiba & $\mathbf{5 7 . 8} \pm \mathbf{6 . 7}$ & $\mathbf{1 7 . 7} \pm \mathbf{2 . 9}$ & $\mathbf{1 1 . 5} \pm \mathbf{1 . 3}$ & $\mathbf{4 . 5} \pm \mathbf{0 . 6}$ & $\mathbf{9 1 . 5} \pm \mathbf{1 1 . 3}$ \\
High & A. Aamar & $\mathbf{1 1 . 8} \pm \mathbf{2 . 1}$ & $\mathbf{2 . 8} \pm \mathbf{0 . 1}$ & $\mathbf{1 . 8} \pm \mathbf{0 . 2}$ & $\mathbf{0 . 7} \pm \mathbf{0 . 1}$ & $\mathbf{1 7 . 1} \pm \mathbf{3 . 1}$ \\
Atlas & Ifghane & $\mathbf{2 7 . 2} \pm \mathbf{4 . 1}$ & $\mathbf{6 . 8} \pm \mathbf{0 . 3}$ & $\mathbf{4 . 4} \pm \mathbf{0 . 3}$ & $\mathbf{1 . 7} \pm \mathbf{0 . 2}$ & $\mathbf{4 0 . 1} \pm \mathbf{5 . 6}$ \\
& Asloul & $\mathbf{1 7 . 4} \pm \mathbf{2 . 2}$ & $\mathbf{3 . 9} \pm \mathbf{0 . 1}$ & $\mathbf{2 . 5} \pm \mathbf{0 . 2}$ & $\mathbf{0 . 9} \pm \mathbf{0 . 3}$ & $\mathbf{2 4 . 5} \pm \mathbf{3 . 1}$ \\
\hline
\end{tabular}

Table 5. Amount of carbon in biomass $\left(\mathrm{Mg} \cdot \mathrm{ha}^{-1}\right)$ of the associated trees (cedar and thuya) and oxycedar.

\begin{tabular}{|c|c|c|c|c|c|c|c|}
\hline & & D. Hachlaf & Ajdir & Ksiba & Aamar & Ifghane & Asloul \\
\hline \multirow{3}{*}{$\begin{array}{c}\mathrm{C} \text { in the } \\
\text { aboveground } \\
\text { biomass }\end{array}$} & Cedar & $34.8 \pm 4.3$ & $66.1 \pm 7.6$ & - & - & - & - \\
\hline & Thuya & - & - & - & $1.1 \pm 0.2$ & $0.9 \pm 0.3$ & - \\
\hline & Oxycedar & $1.0 \pm 0.2$ & $1.4 \pm 0.3$ & - & $3.2 \pm 0.7$ & $0.8 \pm 0.2$ & $2.1 \pm 0.5$ \\
\hline
\end{tabular}

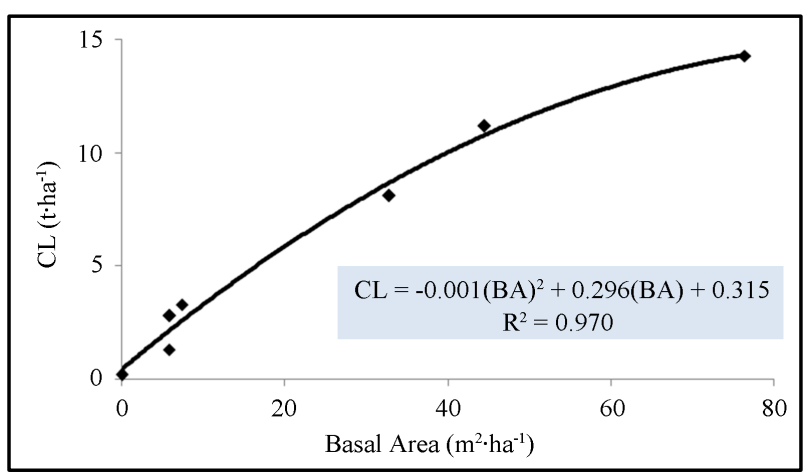

Figure 8. Changes of soil carbon in litter relating to basal area.

0.2 $\mathrm{Mg} \mathrm{C} \mathrm{ha}^{-1}$ in the clearing (C2) stand of High Atlas and 14.3 $\mathrm{Mg} \mathrm{C} \mathrm{ha}^{-1}$ in (Ajdir). Therefore, in the soil litter of evergreen oak forests of Middle Atlas there was a greater amount of soil organic carbon in litter than those evergreen oak forests of High Atlas 11.2 $\mathrm{MgC} \mathrm{ha}^{-1}$ and $2.5 \mathrm{MgC} \mathrm{ha}^{-1}$ respectively.

\section{Discussion}

\subsection{Soil Organic Carbon and Carbon Concentrations}

The soil organic carbon varies according to the depth of soil and the forest management, decreasing with the depth and following the same rate in all experimental stands. The soil depth interval containing greater concentration of organic matter was the first, $0-15 \mathrm{~cm}$. In fact, the organic carbon in Dayat Hachlaf stand was the 6.3\% and the $8.1 \%$ in Ajdir forest stand. The percentage of soil organic carbon in the $15-30 \mathrm{~cm}$ depth interval of soil was $54 \%$ to $65 \%$ lower than the $0-15 \mathrm{~cm}$ soil depth interval. In the same way, the percentage of soil organic carbon in the 30 - $50 \mathrm{~cm}$ depth interval decreased from $57 \%$ to $85 \%$ of its value in relation with the 15 - 30 cm depth interval and from $85 \%$ to $93 \%$ in relation to the $0-15 \mathrm{~cm}$ depth interval.

There was a great variability in the soil organic carbon for the eight stands studied: these amounts decreased quickly with the soil depth and the thickness. This very progressive decrease in the soil organic carbon with the 
soil depth is an interesting characteristic of the distribution (Boulmane et al. 2007, 2010; Chiti et al. 2012; Ouagga 2005; Hounzandji 2009), according to the very progressive loss of the organic character of soil horizons. In our study there isn't a clear limit between the organo-mineral horizons and the underlying horizons. This type of stratification leads us to recognize the layers of transition. Also, the soil organic carbon decreased with the depletion of basal area of the trees $\left(\mathrm{m}^{2} \cdot \mathrm{ha}^{-1}\right)$, however, the stand density (tree $\left.\cdot h a^{-1}\right)$ has not a significant effect. This decrease was more emphasized in the first depth of soil $(0-15 \mathrm{~cm})$.

\subsection{Soil Organic Carbon}

The total amount of organic carbon in a forest ecosystem is great and it is in dynamic equilibrium with its environment. Because of the large areas involved at regional/global scale, forest soils play an important role in the global C cycle. There was a great significant variation among the soil organic carbon at different depth intervals, being highest in the first depth interval $0-15 \mathrm{~cm}$ (more than 53\% of SOC total) of all forest stands. About more than three quarters of the total C pools were stored in upper $30 \mathrm{~cm}$ (Figure 2(a), Figure 2(b)). Eglin (2005) and Lecointe et al. (2005) in British forests have estimated a SOC between $68 \%$ and $75 \%$ of total organic carbon stock in forest soils. In the present study was between $76 \%-93 \%$.

In general, the average value of SOC pool to the depth of $0-100 \mathrm{~cm}$ in the stands of Middle Atlas and High Atlas ranged 3.1 to $141.4 \mathrm{t} \mathrm{Mg} \cdot \mathrm{ha}^{-1}$ in the clearing and Ajdir stand (2124 trees $\cdot \mathrm{ha}^{-1}$ ) respectively (Figure 2(a), Figure 2(b)). This study also indicate that the soil organic carbon $(0-100 \mathrm{~cm})$ in the stands of the Middle Atlas

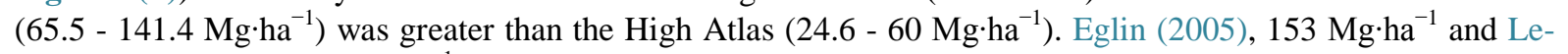

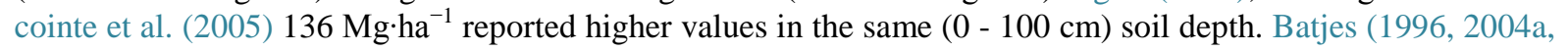
b, 2005a, b), Sombroek et al. (1993), Droogers and Bouma (1997) and Bouma et al. (1998) in forest stands of Brazil, Jordan, India and Kenya respectively showed a high variability of organic carbon stocks in function of soil characteristics. The Tropic soils (at a depth of $0-100 \mathrm{~cm}$ ) have higher soil organic carbon amounts (150 to

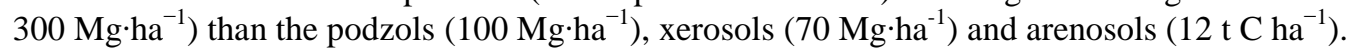

\subsection{Amount of Carbon in Tree Aboveground Biomass}

Inventory and Modelling of Carbon within Biomass

Considering the aboveground biomass of trunk and branches in the oak stands our obtained values of carbon

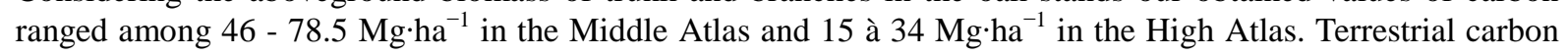
storage is proposed by scientists as an effective mitigation option because it combines mitigation with positive effects on environmental conservation and soil fertility (Smith et al. 2007). Losses of terrestrial carbon are caused by disturbances, such as fire, wind-throw, drought or pests, and through human activities like deforestation and changes in agricultural practices leading to land degradation.

The results average of soil organic carbon amounts of $78.5 \mathrm{Mg} \cdot \mathrm{ha}^{-1}$ in the Middle Atlas and $27.2 \mathrm{Mg} \cdot \mathrm{ha}^{-1}$ in the High Atlas confirm that the oak forest stands in the Middle Atlas sequestrated three or four times more organic carbon content than the oak forest stands in the High Atlas, even if the difference of surface area is in the order of $50 \%$.

\subsection{Amount of Carbon in Litter}

The soil $(0-100 \mathrm{~cm})$, the litter layer and the roots stored approximately the $55 \%$ and $68 \%$ of the total carbon stored in the oak stands of Middle Atlas and Hight Atlas. Regarding only the litter layer the Maroccan oak stands stored about $36 \mathrm{t} \cdot \mathrm{ha}^{-1}$, and this amount represents the $6 \%$ of total carbon stored. Dupouey et al. (1999) reported among 80 and $90 \mathrm{t}^{-\mathrm{ha}^{-1}}$ in the litter layer of temperate forests and (Andreux and Choné, 1993) in tropical forests obtained about 50 à $60 \mathrm{t} \mathrm{C} \mathrm{ha}^{-1}$, whereas, the percentage of carbon stored in the aboveground biomass varies among $35 \%$ and $50 \%$ of the total carbon stored.

\section{Conclusion}

The correlation study showed that the SOC of different forest stands were strongly dependent of soil depth. They decreased following an exponential curve with a negative exponent in all study stands, as well as the deviation among the soil organic carbon of different depth intervals in all study stands decreased with the soil depth. This study also indicated that the soil organic carbon $(0-100 \mathrm{~cm})$ in the stands of the Middle Atlas were greater than 
those in the High Atlas.

The data obtained in the present study confirm the important function of near natural forests as long-term C sinks, in forest biomass, litter and soil. The long term C storage potential of these systems is very high, especially in less-intensively managed forests that include large trees.

Our results on amount of carbon in tree aboveground biomass of the oak forests confirm that the oak forest stands in the Middle Atlas sequestrate three or four times more organic carbon content than the oak forest stands in the High Atlas, even if the difference of surface area is in the order of $50 \%$.

\section{References}

Adams, D. M., Alig, R. J., McCarl, B. A., Callaway, J. M., \& Winnett, S. M. (1999). Minimum Cost Strategies for Sequestering Carbon in Forests. Land Economics, 75, 360-374. http://dx.doi.org/10.2307/3147183

Andreux, F., \& Choné, T. (1993). Dynamics of Soil Organic Matter in the Amazon Ecosystem and after Deforestation: Basis for Efficient Agricultural Management. Nancy: Centre de Recherche Scientifique.

Batjes, N. H. (1996). Total Carbon and Nitrogen in the Soils of the World. European Journal of Soil Science, 47, 151-163. http://dx.doi.org/10.1111/j.1365-2389.1996.tb01386.x

Batjes, N. H. (2004a). Estimation of Soil Carbon Gains upon Improved Management within Croplands and Grasslands of Africa. Environment, Development and Sustainability, 6, 133-143. http://dx.doi.org/10.1023/B:ENVI.0000003633.14591.fd

Batjes, N. H. (2004b). Soil Carbon Stocks and Projected Changes according to Land Use and Management: A Case Study for Kénya. Soil Use and Management, 20, 350-356. http://dx.doi.org/10.1079/SUM2004269

Batjes, N. H. (2005a). Soil Carbon Stocks and Projected Changes within Crosslands in Jordan. Geoderma, 25, 415-423.

Batjes, N. H. (2005b). Organic Carbon Stocks in the Soils of Brazil. Soil Use and Management, 21, 22-24. http://dx.doi.org/10.1079/SUM2005286

Belghazi, B., Ezzahiri, M., Aoid, S., \& El-Tobi, M. (2001). Estimation de la biomasse du chêne vert dans le massif forestier d'Aït Hatem (Oulmes). Annales de la Recherche Forestière au Maroc, 34, 9-16.

Bernoux, M., Cerri, C. C., Volkoff, B., Carvalho, M. C. S., Feller, C., Cerri, C. E. P., Eschenbrenner, V., Piccolo, M. C., \& Brigite, F. (2005). Gaz à effet de serre et stockage du carbone par les sols: Inventaire au niveau du Brésil. Cahiers Agricultures, 14, 96-100.

Boudy, P. (1950). Economie forestière Nord Africaine. Tome II, monographie et traitement des essences forestières. Fasc. I. Edit. Larousse, Paris.

Boulmane, M., Halim, M., El Antry-Tazi, S., Berred, K., \& El Harchaoui, H. (2007). Evaluation du stock du carbone et dynamique de la décomposition de la matière organique dans les sols de la Maâmora. Annales de la Recherche Forestière au Maroc, 39, 185-194.

Boulmane, M., Makhloufi, M., Bouillet, J. P., Saint-André, L., Satrani, B., \& Halim, M. (2010). Estimation du stock de carbone organique dans les Quercus ilex du Moyen Atlas Marocain. Acta Botanica Gallica, 157, 451-467. http://dx.doi.org/10.1080/12538078.2010.10516222

Boulmane, M., Santa-Regina, I., Khia, A., Abbassi, H., \& Halim, M. (2013). Aboveground Biomass and Nutrient Pools in Two Evergreen Oak Stands of the Middle Moroccan Atlas Area. Arid Land Research and Management, 27, $188-202$. http://dx.doi.org/10.1080/15324982.2012.723114

Bouma, J., Batjes, N. H., \& Groot, J. J. R. (1998). Exploring Land Quality Effects on World Food Supply. Geoderma, 86, 43-59. http://dx.doi.org/10.1016/S0016-7061(98)00034-2

Brown, S. (1998). Present and Future Role of Forests in Global Climate Change. In B. Goapl, P. S. Pathak, \& K. G. Saxena (Eds.), Ecology Today: An Anthology of Contemporary Ecological Research (pp. 59-74). New Delhi: International Scientific Publications.

Chiti, T., Diaz-Pinès, E., \& Rubio, A. (2012). Soil Organic Carbon Stock of Conifers, Broadleaf and Evergreen Broadleaf Forests of Spain. Biology and Fertility of Soils, 48, 817-826. http://dx.doi.org/10.1007/s00374-012-0676-3

Davi, H., Dufrêne, E., Granier, A., Le Dantec, V., Barbaroux, C., François, C., \& Bréda, C. (2005). Modelling Carbon and Water Cycles in a Beech Forest Part II: Validation of the Main Processes from Organ to Stand Scale. Ecological Modelling, 1, 1-19.

Droogers, P., \& Bouma, J. (1997). Soil Survey Input in Exploratory Modelling of Sustainable Management Practice. Soil Science Society of America Journal, 61, 1704-1710. http://dx.doi.org/10.2136/sssaj1997.03615995006100060023x

Dupouey, J. L., Pignard, G., Badeau, V., Thimonier, A., Dhôt, J. F., Nepveu, G., Bergès, L., Augusto, L., Belkacem, S., \& Nys, C. (1999). Stocks et flux de carbone dans les forêts françaises. Paris: CRAAF, Edition Académie des Sciences 
Française, 278-292.

Eglin, T. (2005). Impact de l'hydromorphie et la topographie sur la variabilité spatiale des stocks de carbone en forêt de Fougères (Ille-et-Vilaine). Thèse INA, Paris-Grignon.

Ezzahiri, M., Belghazi, B., Romane, F., Qarro, M., \& Sabir, M. (1995). Phytomasse et accroissements du chêne vert dans le dispositif expérimental de Dayat Aoua du Moyen Atlas. Annales de la Recherche Forestière au Maroc, 29, 81-89.

Gallardo, J. F., Santa-Regina, I., Harrison, A. F., \& Howard, D. M. (1995). Organic Matter and Nutrient Dynamics in Three Ecosystems of the "Sierra de Béjar" Mountains (Salamanca Province, Spain). Acta Oecologica, 16, 447-459.

GIEC (2007). Changements climatiques: Bilan des changements climatiques: Rapport de synthèse. Publié à l’intention des décideurs.

Hounzandji, P. I. A. (2009). Effet des transformations des écosystèmes naturels (Cedrus atlantica, Quercus rotundifolia) sur la séquestration de carbone dans le Moyen Atlas (Forêt d'Azrou). Mémoire de $3^{\text {ème }}$ Cycle, ENFI, Salé-Maroc.

Lecointe, S., Nys, C., Walter, C., Forgeard, F., Huet, S., Recena, P., \& Follain, S. (2005). Estimation of Carbon Stocks in a Beech Forest (Fougères Forest): Extrapolation from Plots to the Whole Forest. Annals of Forest Science, 25, 432-451.

Leonardi, S., Santa-Regina, I., Rapp, M., Gallego, H. A., \& Rico, M. (1996). Biomass, Litterfall and Nutrient Content in Castanea sativa Coppice Stands of Southern Europe. Annals of Forest Science, 53, 1071-1081. http://dx.doi.org/10.1051/forest:19960603

Liski, J. (1999). CO $_{2}$ Emissions from Soil in Response to Climatic Warming Are Overestimated the Decomposition of Old Soil Organic Matter Is Tolerant Temperature. AMBIO, 28, 171-174.

Liski, J., \& Westeman, C. J. (1997a). Carbon Storage in Forest Soil of Finland. 1. Effect of Thermal Climate. Biogeochemistry, 36, 239-260. http://dx.doi.org/10.1023/A:1005711024022

Liski, J., \& Westeman, C. J. (1997b). Carbon Storage in Forest Soil of Finland. 2. Size and Regional Patterns. Biogeochemistry, 36, 261-274. http://dx.doi.org/10.1023/A:1005742523056

M.A.T.U.H.E. (2010). Second Communication Nationale Initiale à la Convention Cadre des Nations Unies sur les changements climatiques.

M’hirit, O., \& Benziane, M. (2006). Le cèdre de l’Atlas: Mémoire du temps. Edition Mardaga, Sprimont-Belgique.

Murray, B. C. (2000). Carbon Values, Reforestation, and "Perverse" Incentives under the Kyoto Protocol: An Empirical Analysis. Mitigation and Adaptation Strategies for Global Change, 5, 271-295. http://dx.doi.org/10.1023/A:1009636028776

Ouagga, T. (2005). Etude l'effet des modes d'occupation des sols sur la séquestration du carbone et l'agrégation des sols dans le bassin versant de la Rheraya (Haut Atlas du Maroc). Mémoire de $3^{\text {ème }}$ Cycle, ENFI, Salé-Maroc.

Post, W. H., \& Kwon, K. C. (2000). Soil Carbon Sequestration and Land Use Change: Processes and Potential. Global Change Biology, 6, 327-337. http://dx.doi.org/10.1046/j.1365-2486.2000.00308.x

Rapp, M., Santa-Regina, I., Rico, M., \& Gallego, H. A. (1999). Biomass, Nutrient Content, Litterfall and Nutrient Return to the Soil in Mediterranean Oak Forests. Forest Ecology and Management, 119, 39-49. http://dx.doi.org/10.1016/S0378-1127(98)00508-8

Saint-André, L., \& Picard, N. (2005). Construire des tarifs de cubages, biomasses, minéralomasse. Edité par l’INRA de Nancy, France.

Santa-Regina, I. (2000). Biomass Estimation and Nutrient Pools in Four Quercus pyrenaica in Sierra de Gata Mountains, Salamanca, Spain. Forest Ecology and Management, 132, 127-141.

Santa-Regina, I., Rapp, M., Martín, A., \& Gallardo, J. F. (1997). Nutrient Release Dynamics in Decomposing Leaf Litter in Two Mediterranean Deciduous Oak Species. Annals of Forest Science, 54, 747-760. http://dx.doi.org/10.1051/forest:19970805

Santa-Regina, I., \& Tarazona, T. (2001). Nutrient Cycling in a Natural Beech Forest and Adjacent Planted Pine in Northern Spain. Forestry, 74, 11-28. http://dx.doi.org/10.1093/forestry/74.1.11

Santa-Regina, I., Tarazona, T., \& Calvo, R. (2001). Aboveground Biomass in a Beech Forest and a Scots Pine Plantation in the Sierra de la Demanda Area of Northern Spain. Annals of Forest Science, 54, 261-269. http://dx.doi.org/10.1051/forest:19970304

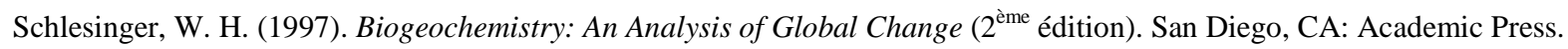

Schoenenberger, A. (1975). Cours d'écologie et botanique forestière. ENFI, 110 p.

Smith, P., Martino, D., Cai, Z., Gwary, D., Janzen, H., Kumar, P., McCarl, B., Ogle, S., O’Mara, F., Rice, C., Scholes, B., \& Sirotenko, O. (2007). Agriculture. In B. Metz, O. R. Davidson, P. R. Bosch, R. Dave, \& L. A. Meyer (Eds.), Climate Change 2007: Mitigation. Contribution of Working Group III to the Fourth Assessment Report of the Intergovernmental Panel on Climate Change, Cambridge, UK and New York: Cambridge University Press. 
Sombroek, W. G., Nachtergaele, F. O., \& Hebel, A. (1993). Amounts, Dynamics and Sequestering of Carbon in Tropical and Subtropical Soils. AMBIO, 22, 417-426.

Torn, M. S., Trumbore, S. E., Chadwick, O. A., Vitousek, P. M., \& Hendricks, D. M. (1997). Mineral Control of Soil Organic Carbon Storage and Turnover. Nature, 139, 170-173. http://dx.doi.org/10.1038/38260

Walkley, J., \& Black, W. (1934) An Experimentation of the Degtjareff Method for Determining Soil Organic Matter, and a Proposed Modification of the Chromic Acid Titration Method. Soil Science, 37, 29-38. http://dx.doi.org/10.1097/00010694-193401000-00003

Watson, R. T., Rhodhe, H., Oeschger, F., \& Siegenthaler, U. (1990). Greenhouse Gases and Aerosols. In J. T. Houghton, G. J. Jenkins, \& J. J. Ephraums (Eds.), Climate Change: The IPCC Scientific Assessment. Cambridge: Cambridge University Press. 